\title{
Control of railway vehicle vibrations due to the effect of different superstructure stiffness in transition zones with rail irregularities
}

\section{Demiryolu geçiş bölgelerinde farklı üstyapı rijitlikleri ve ray düzensizliği nedeniyle oluşan raylı taşıt titreşimlerinin kontrolü}

\author{
Arif ULU ${ }^{1}$ (D), Muzaffer METIN²* iD \\ 1Department of Mechanical Engineering, Faculty of Engineering, Istanbul Aydin University, Istanbul, Turkey. \\ arifulu@aydin.edu.tr \\ 2Department of Mechanical Engineering, Faculty of Mechanical Engineering, Yildiz Technical University, Istanbul, Turkey. \\ mmetin@yildiz.edu.tr
}

\begin{abstract}
While railway vehicles are moving, a sudden change of superstructure stiffness in crossings at the starting and ending points of tunnels or bridges leads to undesired vibrations both on the track structure and in the vehicle. In this paper, simulations are performed by using a onedimensional train-track coupled dynamic model under the condition of a light rail vehicle passed through a slab superstructure line with different stiffness values as a transition zone of the railway. The actual conditions used in Istanbul transportation are taken into account in the modelling of the track and the light metro vehicle. The model of the track consists of an Euler-Bernoulli beam resting on discrete supported rail pads, which are connected as a viscoelastic foundation to a rigid ground. The vertical vibrations are analyzed by a model in which track and 16 DOF semi-vehicle models are combined, including a dynamic wheel-rail contact. Two different controllers are designed in parallel with secondary suspensions in order to suppress vertical vibrations of the light rail vehicle resulting from the change in the dynamic conditions of the superstructure and the rail irregularity in the transition zone to increase the comfort of the passengers. For many simulation scenarios, including unloaded and fully loaded vehicle conditions at the average and maximum operational speeds, with and without track irregularities, the superiority of the fuzzy logic controller over the commonly used PID controller is shown in the time and frequency domain.
\end{abstract}

Keywords: Railway transition zones, track stiffness, railway vehicle dynamics, track dynamics, vibration control, fuzzy logic control.

\section{Introduction}

Changes in the vertical stiffness of railway tracks, called transition regions, are found in rigid track structures such as the entrance or exit points of tunnels, bridges or railway switches [1],[2]. Previous and following abrupt changing may cause structural and comfort-related problems in tracks and trains. Besides transition zones, some track problems (swing rail pads, pumping ballast and rail deformations) also disturb the comfort levels of passengers [3]-[7]. All these effects may lead to a higher operation, repair cost, and especially, risks of derailment [8]-[10]. Investigation and suppression of trains' dynamic responses at transition zones have become more important in terms of passenger comfort.

\section{Öz}

Demiryolu araçları hareket ederken, tünellerin veya köprülerin başlangıç ve bitiş noktalarındaki geçişlerde ani bir üstyapı sertliği değişikliği, hem ray yapısında hem de araçta istenmeyen titreşimlere neden olur. Bu çalıșmada, demiryolu geçis bölgesi olarak ele alınan farklı sertlik değerlerine sahip rijit bir üst yapı hattından geçen hafif raylı tașita dair, tek boyutlu tren-yol dinamik model çifti kullanılarak simülasyonlar yapılmıştır. Hafif metro aracı ve yol İstanbul ulaşımında kullanılan gerçek koșullar dikkate alınarak modellenmiștir. Rayın modeli, sert bir zemine viskoelastik bir temel olarak bağlanan ayrık desteklenmis ray pedleri üzerine oturan bir Euler-Bernoulli kirișten olușur. Düșey titreșimler, dinamik bir tekerlek-ray teması içeren yol ve 16 serbestlik dereceli yarım taşıt modellerinin birleștirildiği bir model ile analiz edilmistir. Íkincil süspansiyonlara paralel olarak çalıșmak üzere, üstyapının dinamik koșullarının değişimi ve ray düzensizlikleri sonucu hafif metro aracında ortaya çıkan düșey titreșimlerin bastırılması için iki farklı kontrolör tasarlanmıștır. Ortalama ve maksimum ișletme hızlarında, ray düzensizlikleri olan ve olmayan, yüksüz ve tam yüklü araç koșulları dahil olmak üzere birçok simülasyon senaryosunda, bulanı mantık denetleyicisinin yaygin olarak kullanılan PID denetleyicisine göre üstünlüğü zaman ve frekans alanında gösterilmiştir.

Anahtar kelimeler: Demiryolu geçiş bölgesi, demiryolu araç dinamiği, yol dinamiği, titreșim kontrolü, bulanık mantıklı kontrol.

Previous studies were concerned with either controlling railway vehicle motions or finding the optimum track stiffness or developing a suitable design method for transitions [11]. Hot-Mix-Asphalt (HMA) layer [12] steel bars [9], pilling [13], under sleeper pads (USP) [10],[12],[14], additional rails [15], [16], and variable timbers [17], and backfills [18] are some structural solutions for transition zones. However, ballast settlements, rail pad aging or railhead deformations may cause vibrations any time.

Control studies generally include the suppression of effects caused by railway disturbances. The dynamic models used in these studies do not include the transitions of the railway superstructure. Passive [19], active [20]-[27] and semi-active [28]-[32] vibration controllers are widely used in theory. Moreover, actuator dynamics [30],[31],[33],[34] may also be added to control algorithms. Main purposes of control

${ }^{*}$ Corresponding author/Yazışılan Yazar 
strategies are to improve ride safety and passenger comfort and estimate statuses of rail vehicle models [35].

In the literature review, a study on the reduction of the effects of transition dynamics on the railway vehicle could not found to model the railway superstructure together with the vehicle. To minimize the dynamic effects of transition zones on railway vehicles, two control algorithms are studied in four different scenarios for showing the robustness values and performances of controllers. The modelled light railway transportation (LRT) vehicle is used in the Istanbul light rail line, and the modelled transition zone is located in the Kirazl-Yenikapı metro line (Figure 1). In this paper, at first, the combined model is introduced, then the controllers are modelled together with several scenarios, and the results are analysed and presented at the end of this study.

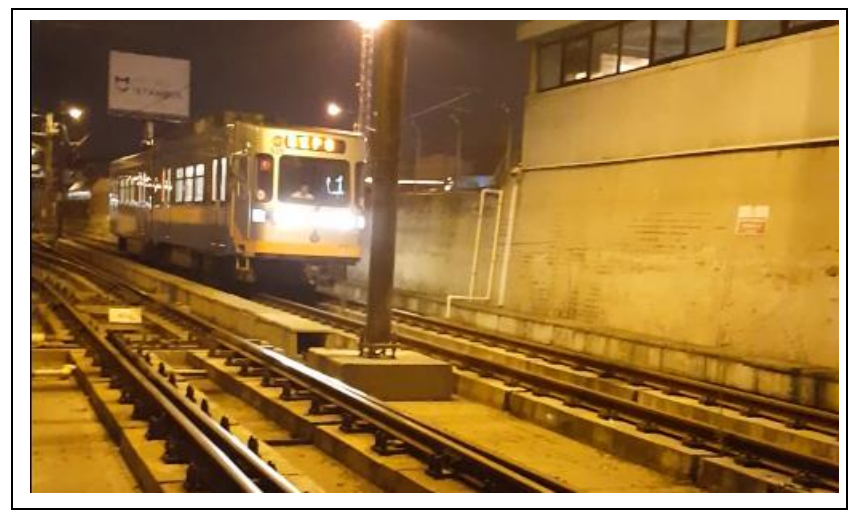

Figure 1. Modeled light rail vehicle and rigid track.

\section{Modelling of the train-track coupled system}

The superstructure and railway vehicle system pair were modelled in two parts. The LRT vehicle system consisted of two car bodies, three bogies, and six wheels, while the rigid superstructure consisted of concrete structures, rails, rail pads and fasteners. These two parts of the coupled model were combined with a Hertz spring, and the vehicle dynamic was added to the road dynamics by moving wheel-rail contact [3],[4],[7]. The LRT vehicle was modeled to have 16 degrees of freedom, which described the bouncing and pitching motions of the vehicle bodies $\left(M_{c 1}, M_{c 2}\right)$, their bogies $\left(M_{b 1}, M_{b 2}, M_{b 3}\right)$ and wheelsets $\left(M_{w 1}, M_{w 2}, M_{w 3}, M_{w 4}, M_{w 5}, M_{w 6}\right)$. In another paper [23], detailed information may be found about this rail vehicle. All parameter values for the modelled rail vehicle are given in Table 1.
In fact, the train-track interaction was considered as a movingload on an elastic foundation. It was dealt with as a dynamically changing contact force in this study. The model of the track consisted of an Euler-Bernoulli beam resting on discrete supported rail pads, which were connected as a viscoelastic foundation to a rigid ground (Figure 2).

In this study, the dynamic behaviour of the railway consisted of three zones: stiff-soft-stiff. Therefore, the transition effects on railway vehicle bodies could be examined separately for the entrance and exit. The change of rail pad stiffness along the line is shown in Figure 3. All the values of rail pad stiffness $\left(k_{r p 1}, k_{r p 2}, k_{r p 3}\right)$, the damping coefficients $\left(c_{r p 1}, c_{r p 2}, c_{r p 3}\right)$ and the distances between the rail pads $\left(\eta_{1}, \eta_{2}, \eta_{3}\right)$ are given in Table 2. All modelling parameters were provided by Metro Istanbul Co., which is responsible for all local rail transportation and is a company of Istanbul Metropolitan Municipality.

The dynamic of wheel-rail contact was modelled with the Hertz theory. Thus, the forces $\left(F_{h}\right)$ between the vehicle and the track were provided by a linear Hertz spring defined by the coefficient $k_{h}$.

$$
\begin{gathered}
F_{h}=k_{h}\left(z_{w}-w_{r}-z_{r}\right) \\
k_{h}=(3 / 2) c_{h}{ }^{3 / 2} P_{w}{ }^{1 / 3} \\
c_{h}=\left(4.57 R_{w}{ }^{-0.149} 10^{-8}\right)^{-3 / 2}
\end{gathered}
$$

Where, $F_{h}, k_{h}$ and $c_{h}$ denote the Hertzian contact force, coefficient of Hertz spring and Hertz constant based on the master and slave surfaces (rail and wheel), respectively. $z_{w}, w_{r}$ and $z_{r}$ are displacement of the wheel, displacement of the rail in the contact point and rail surface irregularity, respectively. $P_{w}$ and $R_{w}$ are respectively the measured static forces and the radius of wheels.

\subsection{Equations of motion}

Firstly, kinetic and potential energies of the train and track system were derived, and then, differential equations (DE) of motions were found by means of the Lagrange energy method, as given below.

$$
\frac{d}{d t}\left(\frac{\partial E_{k}}{\partial \dot{x_{\imath}}}\right)-\frac{d E_{p}}{d x_{i}}+\frac{d E_{d}}{d \dot{x_{\imath}}}=Q_{i}
$$

\begin{tabular}{|c|c|c|c|}
\hline $\begin{array}{c}\text { Mass } \\
\text { Parameters (kg) }\end{array}$ & $\begin{array}{c}\text { Stiffness } \\
\text { Parameters }(\mathrm{N} / \mathrm{m})\end{array}$ & $\begin{array}{c}\text { Damping } \\
\text { Parameters (N.s/m) }\end{array}$ & $\begin{array}{c}\text { Other } \\
\text { Parameters }\end{array}$ \\
\hline $\begin{array}{c}\mathrm{M}_{\mathrm{c} 1,2}=4500 \\
\mathrm{M}_{\mathrm{b} 1}=2400 \\
\mathrm{M}_{\mathrm{b} 2}=1550 \\
\mathrm{M}_{\mathrm{b} 3}=2400 \\
\mathrm{~J}_{\mathrm{b} 1}=1540 \\
\mathrm{~J}_{\mathrm{b} 2}=960 \\
\mathrm{~J}_{\mathrm{b} 3}=1540 \\
\mathrm{M}_{\mathrm{w} 1}, \mathrm{M}_{\mathrm{w} 2}=275 \\
\mathrm{M}_{\mathrm{w} 3}, \mathrm{M}_{\mathrm{w} 4}=275 \\
\mathrm{M}_{\mathrm{w} 5}, \mathrm{M}_{\mathrm{w} 6}=275\end{array}$ & $\begin{array}{c}\mathrm{k}_{21}, \mathrm{k}_{22}, \mathrm{k}_{23}=7244 \\
\mathrm{k}_{22}=8 \times 10^{9} \\
\mathrm{k}_{11}, \ldots, \mathrm{k}_{66}=1.6 \times 10^{6}\end{array}$ & $\begin{array}{l}\mathrm{c}_{21}, \mathrm{c}_{22}, \mathrm{c}_{23}=4 \times 10^{5} \\
\mathrm{c}_{11}, \ldots, \mathrm{c}_{66}=1.1 \times 10^{5}\end{array}$ & $\begin{array}{c}\mathrm{L}_{\mathrm{a}}=0.9 \mathrm{~m} \\
\mathrm{~L}_{\mathrm{t}}=3.2 \mathrm{~m} \\
\mathrm{P}_{\mathrm{w} 1, \ldots, 6}=27578 \mathrm{~N} \\
\mathrm{R}_{\mathrm{w}}=0.64 \mathrm{~m} \\
\xi_{1}=0 \mathrm{~m} \\
\xi_{2}=1.8 \mathrm{~m} \\
\xi_{3}=8.0 \mathrm{~m} \\
\xi_{4}=9.8 \mathrm{~m} \\
\xi_{5}=16 \mathrm{~m} \\
\xi_{6}=17.8 \mathrm{~m} \\
\eta_{1,3}=0.6 \mathrm{~m} \\
\eta_{2}=0.5 \mathrm{~m}\end{array}$ \\
\hline
\end{tabular}

Table 1. Train vehicle parameters. 
Table 2. Track parameters.

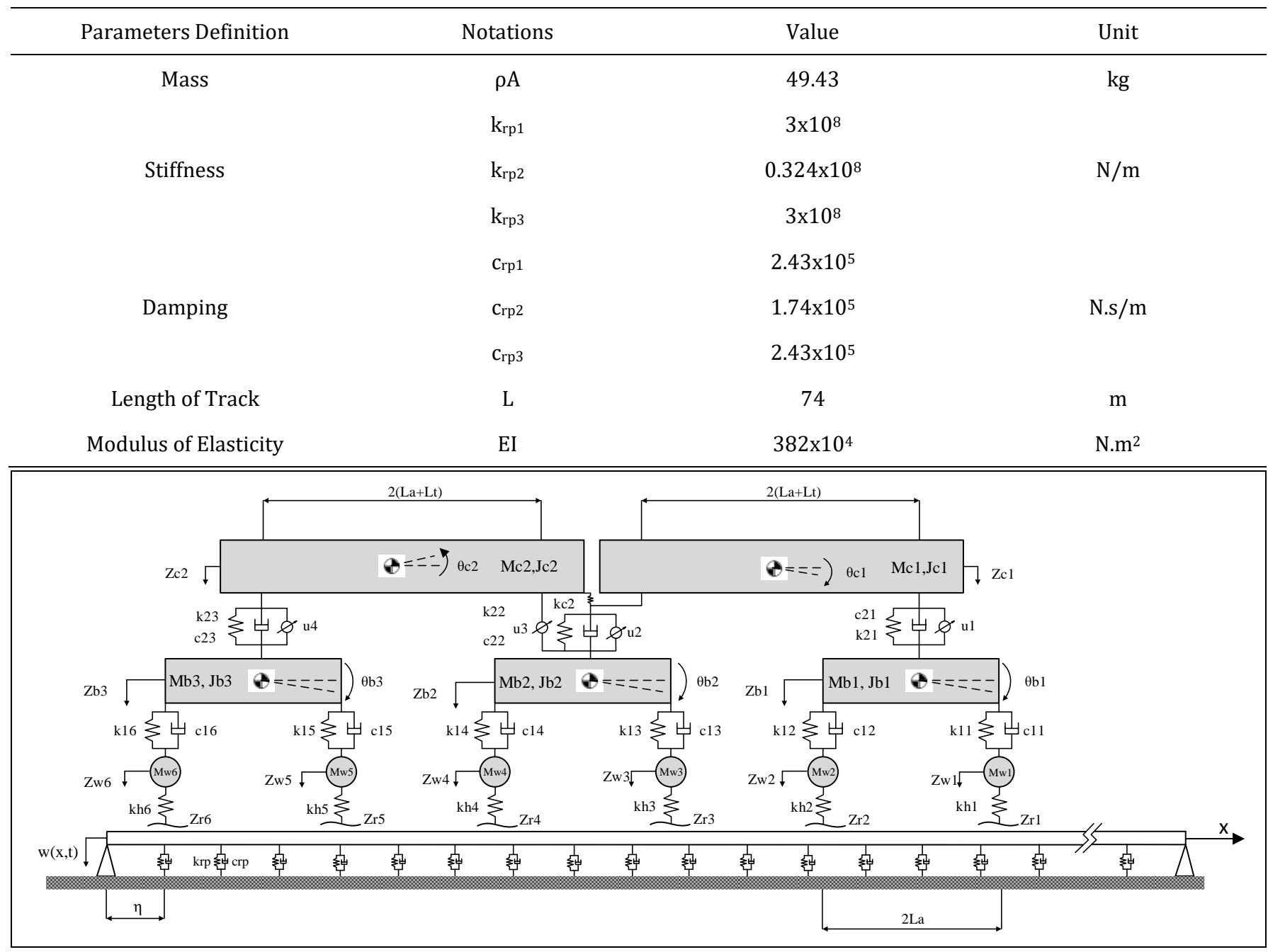

Figure 2. Train track coupled system.

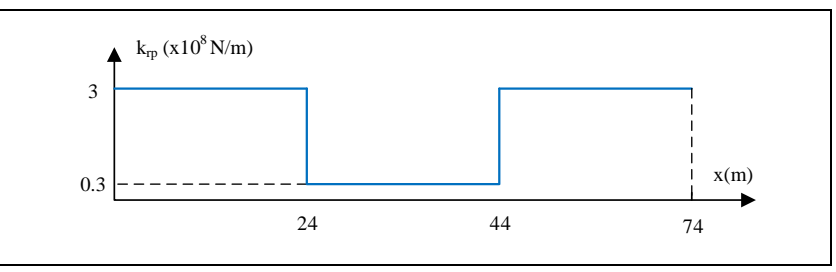

Figure 3. Variation of track stiffness along the track.

Where $E_{k}, E_{p}$ and $E_{d}$ represent the kinetic, potential and dissipation energies of the system, and $Q_{i}$ and $x_{i}$ denote generalized forces and coordinates, respectively. Also, principle of d'Alembert can be used for DEs [36].

The derived DEs for the track system are continuous systems and also partial differential equations (PDE). One more step is needed to convert PDEs into ordinary differential equations (ODE), so that all equations are ready to be solved. Assumed mode or Galerkin's method may be used for obtaining ODEs as below.

$$
E I \frac{\partial^{4} w}{\partial x^{4}}+\rho \mathrm{A} \frac{\partial^{2} w}{\partial t^{2}}+k_{r p}(\mathrm{x}) \mathrm{w}+c_{r p}(\mathrm{x}) \frac{\partial w}{\partial t}=\sum F
$$

$E, I, L, \rho, A, k_{r p}$ and $c_{r p}$ denote the Young's modulus, second moment of inertia, length, density and cross-sectional area of the rail, stiffness and damping coefficients of visco-elastic foundations, respectively. $F$ represents all forces acting on the rail from the railway vehicle. The values of $k_{r p}$ and $c_{r p}$ are variable along the track. Appendix A shows all the derived equations. The derived equations were divided into two parts called the train and track subsystems. The interaction of the two subsystems was provided by the wheel-rail interaction forces $\left(F_{w}\right.$ and $\left.F_{R w}\right)$ shown in Figure 4. So, it became a simple train subsystem to implement a controller algorithm. All the governed equations were solved in MATLAB by using a fixed step size (2e-5) with the ode8 solver.

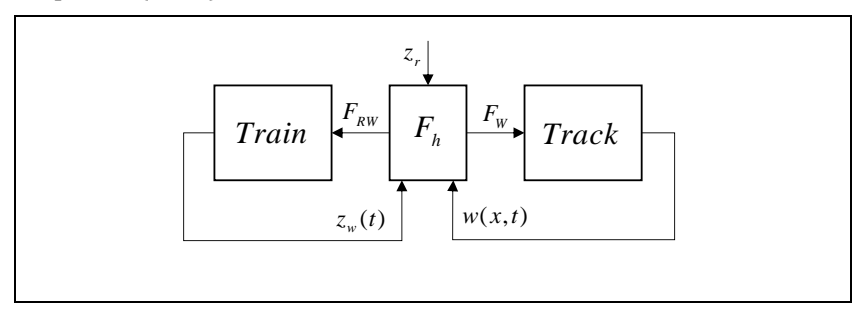

Figure 4. Coupled system interaction. 


\section{Design of controllers}

The aim of this study is to increase passenger comfort by suppressing the vibrations on a railway vehicle with active control methods. Controllers based on PID and fuzzy logic (FL) were designed for this purpose, and actuators were thought to be placed between the vehicle bodies and bogies to suppress the vibrations. In addition to the transition vibrations, the effects of the vibrations induced by rail irregularity for the fully loaded and empty vehicle on the human body and the train were investigated. The success of the control algorithms was evaluated as Power Spectral Density (PSD) and Integral Square Error (ISE) and are presented in the results section.

A control force was applied to the system at four different points in order to reduce the vertical vibration of the railway vehicle. These were $u_{1}, u_{2}, u_{3}$ and $u_{4}$ to suppress the vertical motions of the vehicle bodies. For an instance, $u_{1}$ controlled the front of first car body, so, the input of $u_{1}$ was $z_{p}(t)=\left(z_{c 1}(t)+\left(L_{a}+L_{t}\right) \theta_{c 1}(t)\right)$ for displacement and $\dot{z}_{p}(t)=\left(\dot{z}_{c 1}(t)+\left(L_{a}+L_{t}\right) \dot{\theta}_{c 1}(t)\right)$ for velocity of pivot point.

\subsection{PID control}

Due to its simplicity, PID and its variations are widely used in industrial closed-loop processes [37]. It is also possible that PID control will continue to be used in the future. It has had a revolutionary impact in almost all areas where feedback is applied, and it will continue to do so. The PID control algorithm is perhaps the most basic feedback form in the control area [38],[39]. The PID controller is a compensator that uses proportional, integrator and derivative effects, allowing the system output to follow the reference signal. The closed-loop block diagram of the PID controller and its mathematical representation are well known. The control input for a conventional PID controller is obtained as follows:

$$
u(t)=K_{p} e(t)+K_{i} \int_{0}^{t} e(t) d t+K_{d} \frac{d e(t)}{d t}
$$

Where $e(t)$ is the control error, and the proportional, integral and derivative controller gains are $K_{p}, K_{i}$ and $K_{d}$, respectively.

\subsection{Fuzzy logic control}

Fuzzy logic studies were first introduced in 1965 by Zadeh [40] in a seminal study. Using this introduction, fuzzy logic systems have been developed, and a wide variety of engineering problems have been solved, whereas these problems included controller design, linear and nonlinear system modelling. Fuzzy logic controllers for controller design were introduced by Mamdani and Assilian [41]. An FLC presents a methodology with a decision-making mechanism that is similar to humans' heuristic knowledge to determine how a system is to be controlled. In this study, a FLC design was performed by using the MATLAB Simulink Fuzzy Toolbox.

The structure of the FLC was established based on fuzzification, rule table, fuzzy reasoning engine and defuzzification. In this control structure, the inputs of the controllers are errors $(e(t))$ and their derivatives $(d e(t) / d t)$, and the outputs of the controllers are the actuator forces [23]. Four control forces were applied to the system to suppress the LRT vehicle vibrations. These forces related to the FLCs were $u_{1}, u_{2}, u_{3}$ and $u_{4}$ (Figure 1), whereas these were used to suppress the sum of vertical and pitch motions of the pivot points of the LRT vehicle bodies. The reference values were considered to be zero. See Figure 5 for the FLC block diagram.

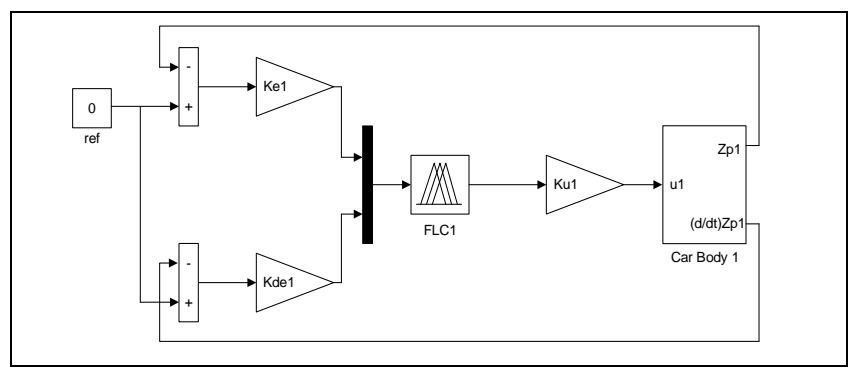

Figure 5: FLC controller structure.

The rule table for the first input $(e(t))$ was classified as $N B, N S, Z P S$ and $P B$, while the second input $(d e(t) / d t)$ was denoted as $N, Z$, and $P$. The output $(u(t))$ was established by the use of linguistic variables $N B B, N B, N M, N S, Z, P S, P M, P B$ and $P B B$. The inputs and output were normalized in the range of $[-1,1]$ as shown in Figure 5 . These input and output scripts $P, N, B, M$ and $S$ represent "positive", "negative", "zero", "large", "medium" and "small" linguistic variables, respectively. A trial and error approach were used with triangular membership functions to achieve good controller performance. The Mamdani and Centroid methods were used for the fuzzification and defuzzification procedures, respectively.

In this case, because of the outputs of the Fuzzy logic functions in the range of $[0,1]$, it was necessary to use the scaling factors $K_{e}, K_{d e}, K_{u}$ as seen in Figure 6.

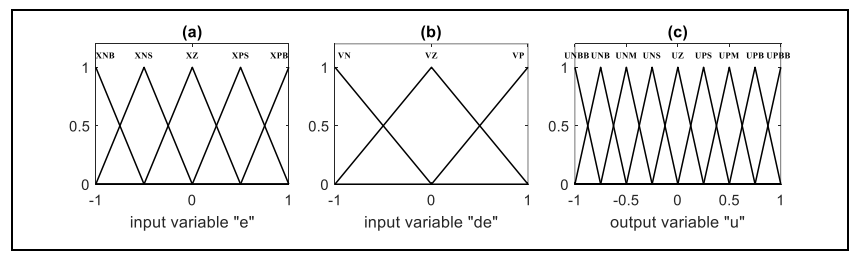

Figure 6. FLC membership functions. (a): For $K_{e}$.(b): For $K_{d e}$. (c): For $K_{u}$.

\section{Simulation results}

At this phase, rail vehicle vibrations that occurred in the transition zones where railway superstructure stiffness characteristics changed are aimed to be suppressed by using two different controllers for four different scenarios, and the success levels of the controllers were compared. The scenarios developed to demonstrate the success and stability of the controllers are given in Table 3.

Two different vehicle speed behaviours were investigated in simulation studies. $50 \mathrm{~km} / \mathrm{h}$ is the average operating speed of the rail vehicle, and it is mainly used to travel at this speed. 80 $\mathrm{km} / \mathrm{h}$ is the maximum permissible travel speed of the rail vehicle and represents an extremity in terms of speed.

Table 3. Situations of created scenarios.

\begin{tabular}{|c|c|c|c|c|}
\hline \multicolumn{5}{|c|}{ Number of Scenario } \\
\hline $\begin{array}{l}\text { Situation of } \\
\text { Scenarios }\end{array}$ & 1 & 2 & 3 & 4 \\
\hline Transition zone & Exist & Exist & Exist & Exist \\
\hline $\begin{array}{l}\text { Load condition of } \\
\text { rail vehicle }\end{array}$ & Unloaded & Unloaded & $\begin{array}{l}\text { Fully- } \\
\text { loaded }\end{array}$ & $\begin{array}{l}\text { Fully- } \\
\text { loaded }\end{array}$ \\
\hline Rail irregularity & Absent & Exist & Absent & Exist \\
\hline $\begin{array}{l}\text { Longitudinal } \\
\text { velocity of rail } \\
\text { vehicle }\end{array}$ & $\begin{array}{c}50 \\
(\mathrm{~km} / \mathrm{h})\end{array}$ & $\begin{array}{c}50 \\
(\mathrm{~km} / \mathrm{h})\end{array}$ & $\begin{array}{c}80 \\
(\mathrm{~km} / \mathrm{h})\end{array}$ & $\begin{array}{c}80 \\
(\mathrm{~km} / \mathrm{h})\end{array}$ \\
\hline
\end{tabular}


Due to the importance of passenger comfort level, amplitude and acceleration of vehicle bodies' vertical $(z)$ and rotation $(\theta)$ motions were evaluated in the time domain as well as the frequency domain with PSD diagrams for the two control strategies. Additionally, the forces required by the actuators were compared for efficiency. Thus, at similar levels of the control force, it could be discussed which controller produced more successful results.

The values of the designed gains and scaling factors of the controllers may be seen in Table 4 .

Table 4. Controller parameters.

\begin{tabular}{cc}
\hline PID Controller Parameters & FLC Parameters \\
\hline $\mathrm{K}_{\mathrm{p}}=6 \times 10^{8}$ & $\mathrm{~K}_{\mathrm{e} 1, \ldots .4}=5 \times 10^{4}$ \\
$\mathrm{~K}_{\mathrm{i}}=10$ & $\mathrm{~K}_{\mathrm{de} 1, \ldots, 4}=10$ \\
$\mathrm{~K}_{\mathrm{d}}=5$ & $\mathrm{~K}_{\mathrm{u} 1, \ldots, 4}=5 \times 10^{4}$ \\
\hline
\end{tabular}

4.1 The First Case: Unloaded vehicle at $50 \mathrm{~km} / \mathrm{h}$ operating speed under the railway transition effect without rail irregularities

At this stage, the simulations were carried out only in the case of the transition zone and included stiff-soft-stiff rail pads at the operational speed of $50 \mathrm{~km} / \mathrm{h}$ with straight and smooth rails as mentioned. The vertical and angular displacement and acceleration responses of the first and second vehicle bodies are shown in Figures 7 and 8, respectively. Figures 9 and 10 show the PSDs of the first and second vehicle bodies' acceleration values and control forces. When the acceleration of the vertical motion was examined, the FLC achieved very successful results up to $80 \mathrm{~Hz}$, while the PID was successful up to $60 \mathrm{~Hz}$. Moreover, when the acceleration of angular motion was examined, the FLC was successful until $50 \mathrm{~Hz}$, and the PID was successful up to $40 \mathrm{~Hz}$. However, while both controllers produced the same level of control force, it was understood that the FL controllers were more effective than the PID controllers in suppressing vibrations, as it may be seen in Figures 7-10.
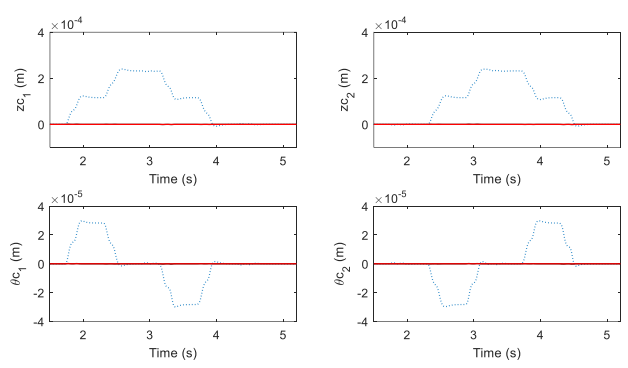

Figure 7. First and second car body displacements

( $\cdots$ Passive, - PID, ---Fuzzy).

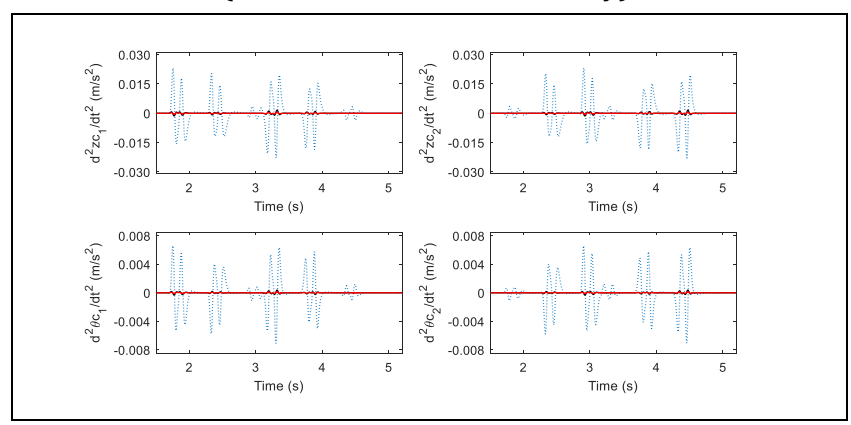

Figure 8. First and second car body accelerations

$$
\text { ( } \cdots \text { Passive, - PID, ---Fuzzy). }
$$
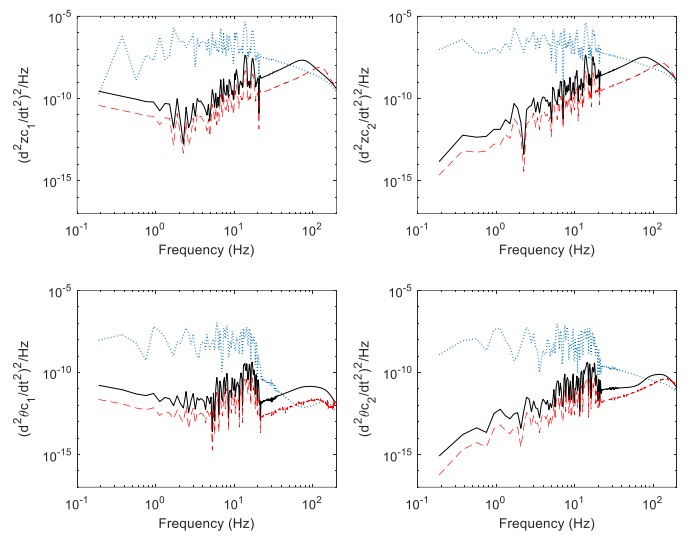

Figure 9. First and second car body PSD graphics

$$
\text { ( } \cdots \text { Passive, - PID, ---Fuzzy). }
$$

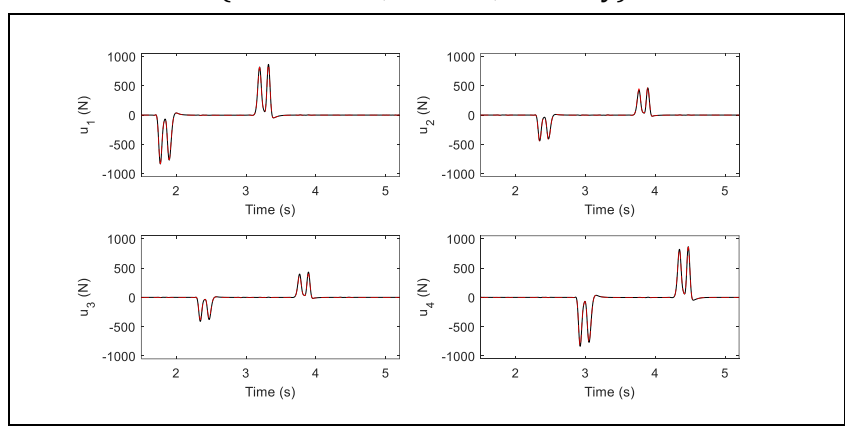

Figure 10. Comparison of control forces ( - PID, --- Fuzzy).

4.2 The Second Case: Unloaded vehicle at $50 \mathrm{~km} / \mathrm{h}$ operating speed under the railway transition effect with rail irregularities

Irregularity in railway lines is an important variable for passenger comfort and driving safety. Over time, many shortor long-wavy irregularities may occur in railways, both by wheel-track interaction and by the way the road is affected by environmental conditions and vehicle load. These random effects may be simulated with a PSD function as determined by the Federal Rail Management (FRA) as follows [7],

$$
S(\Omega)=\frac{A_{v} \Omega_{c}^{2}}{\left(\Omega^{2}+\Omega_{r}^{2}\right)\left(\Omega^{2}+\Omega_{c}^{2}\right)}
$$

In this paper, a rail irregularity was produced according to the FRA class 6 with a maximum amplitude of $\pm 2 \mathrm{~mm}$ (Table 5 and Figure 11). At this stage, the unloaded rail vehicle was simulated for a region with rail irregularity and a transition zone. Thus, in comparison to the results obtained at the previous stage, the results obtained at this stage may be used to better see how the transition effects affected the dynamic response of the vehicle in comparison to the rail irregularity.

Table 5: Track PSD model parameters [7].

\begin{tabular}{cccc} 
FRA class & 4 & 5 & 6 \\
$A_{\mathrm{v}}$ & $2.39 \times 10^{-5}$ & $9.35 \times 10^{-6}$ & $1.5 \times 10^{-6}$ \\
$\Omega_{\mathrm{r}}$ & $2.06 \times 10^{-2}$ & $2.06 \times 10^{-2}$ & $2.06 \times 10^{-2}$ \\
$\Omega_{\mathrm{c}}$ & 0.825 & 0.825 & 0.825 \\
\hline
\end{tabular}




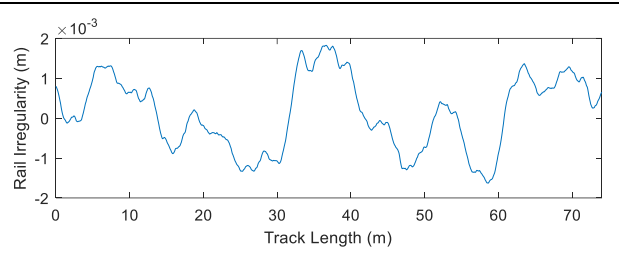

Figure 11. Generated rail irregularity at Class 6.

Figures 12 and 13 show the vertical and angular displacements and accelerations of the vehicle body, respectively. The same controller parameters as the previous stage were used, and a significant reduction in displacements and accelerations was achieved by the controllers.

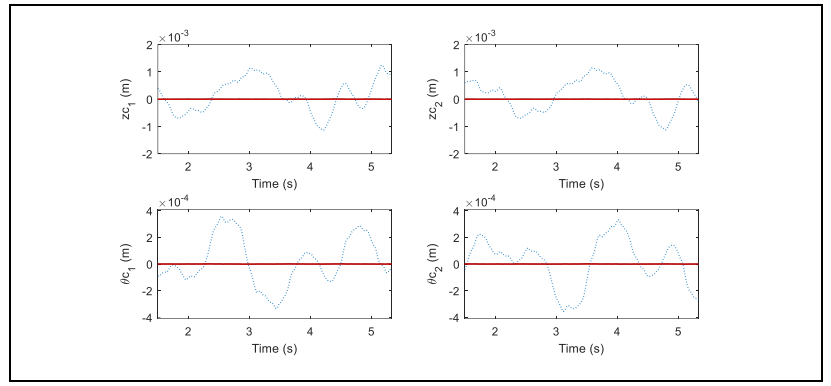

Figure 12. First and second car body displacements ( $\cdots$ Passive, - PID, ---Fuzzy).

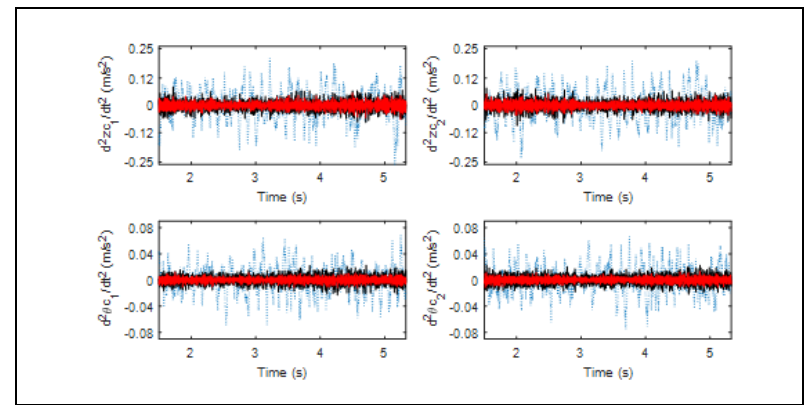

Figure 13. First and second car body accelerations

$$
\text { ( } \cdots \text { Passive, - PID, ---Fuzzy). }
$$

For the comparison of the two controllers in the frequency domain, the PSD diagrams of the vehicle bodies' vertical and angular accelerations were examined in the range from 0.1 to $200 \mathrm{~Hz}$ (Figure 14).

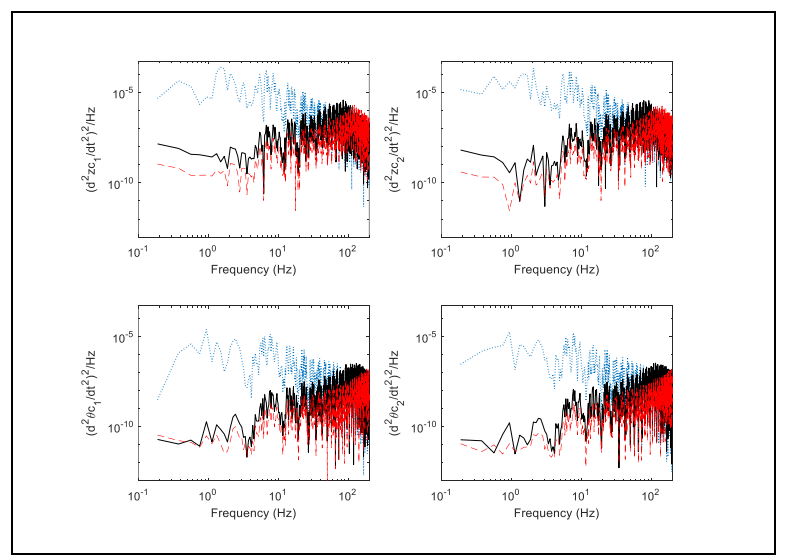

Figure 14. First and second car body PSD graphics

$$
\text { ( } \cdots \text { Passive, - PID, ---Fuzzy). }
$$

At this stage, the results were similar to those in the first scenario in terms of controller success in the frequency domain. However, the control forces that were produced in the first scenario were below $1000 \mathrm{~N}$, where they were below $6000 \mathrm{~N}$ under the rail irregularity condition. In Figure 15, it is seen that very similar forces were produced by both controllers.

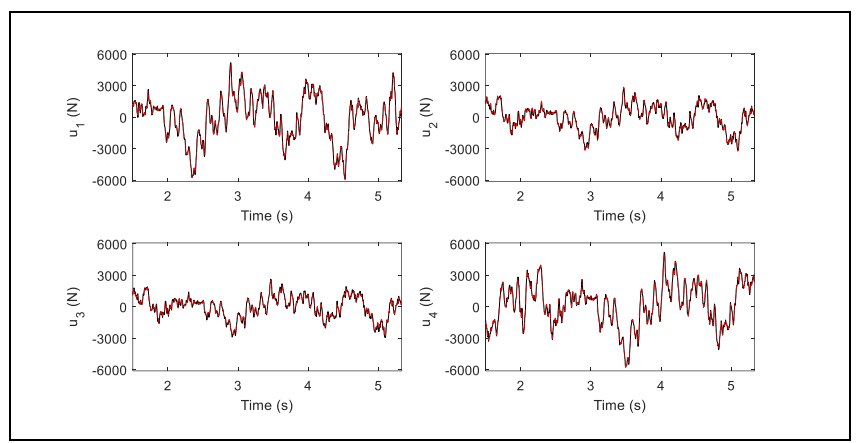

Figure 15. Comparison of control forces ( - PID, --- Fuzzy)

As a result, the vibrations were significantly suppressed by both controllers. However, FLC was more effective than PID in reducing vibrations.

\subsection{The Third Case: Fully loaded vehicle at $80 \mathrm{~km} / \mathrm{h}$ maximum operating speed under the railway transition effect without rail irregularities}

At this stage, the loaded rail vehicle was simulated at a maximum operating speed of $80 \mathrm{~km} / \mathrm{h}$ while traveling on a smooth rail surface without rail irregularity. Figures 16 and 17 show the vehicle bodies' vertical and angular displacements and accelerations under the mentioned conditions, respectively.

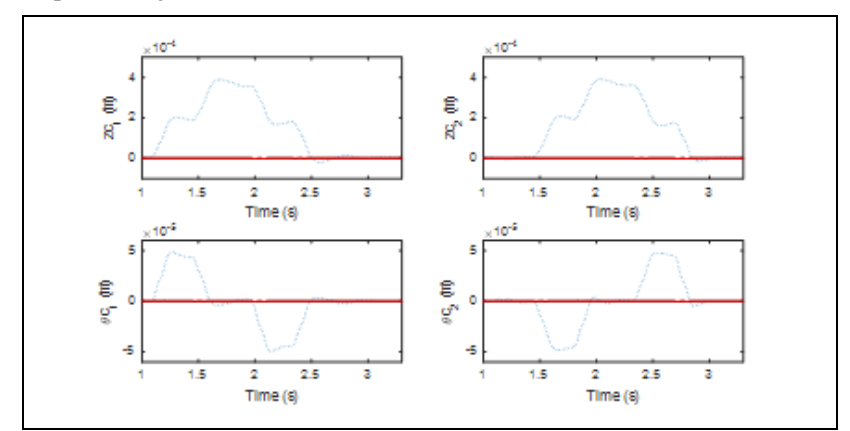

Figure 16. First and second car body displacements ( $\cdots$ Passive, - PID, ---Fuzzy).

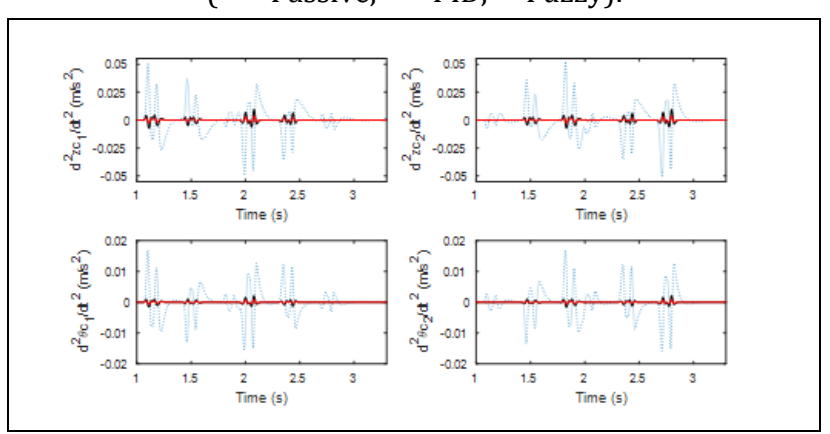

Figure 17. First and second car body accelerations ( $\cdots$ Passive, - PID, ---Fuzzy). 
The dynamic response levels of the rail vehicle body were almost doubled in comparison to the unloaded state mentioned in the first simulation results section. While using the same controller parameters, the vibrations below $60 \mathrm{~Hz}$ in the vertical direction were successfully suppressed by the FLC, while the PID had a success up to $30 \mathrm{~Hz}$ (Figure 18).

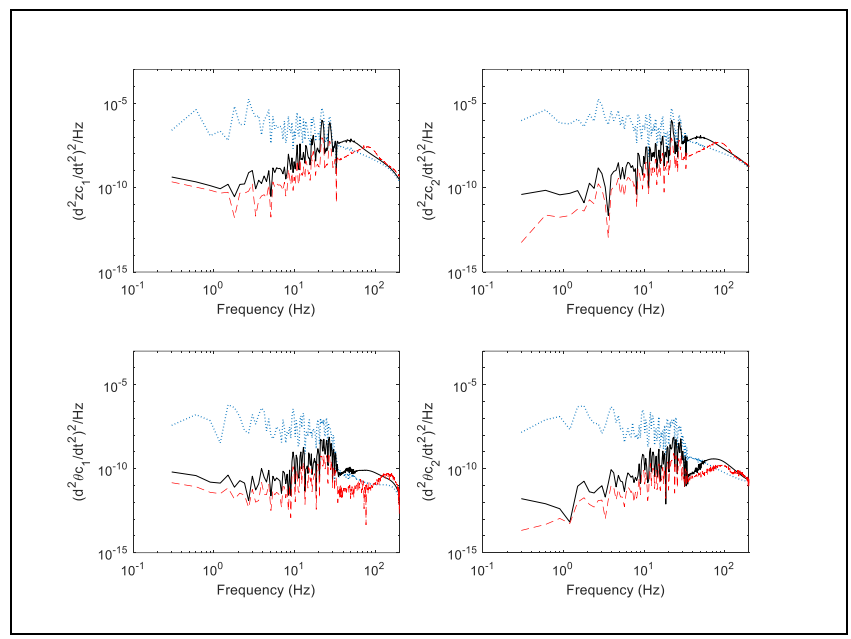

Figure 18. First and second car body PSD graphics

$$
\text { ( } \cdots \text { Passive, - PID, ---Fuzzy). }
$$

Moreover, when the acceleration of angular motion was examined, the FLC was successful up to $90 \mathrm{~Hz}$, and the PID was successful up to $30 \mathrm{~Hz}$. As shown in Figure 19, the control force values were doubled in a similar manner to the acceleration responses, with a maximum control force of about $2000 \mathrm{~N}$.

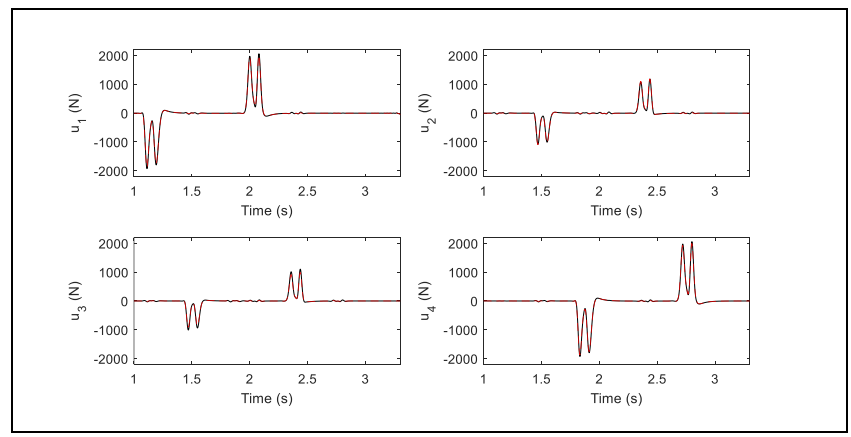

Figure 19. Comparison of control forces ( - PID, --- Fuzzy).

4.4 The Fourth and Worst Case: Fully loaded vehicle at $80 \mathrm{~km} / \mathrm{h}$ maximum operating speed under the railway transition effect with rail irregularities

In the final simulation scenario, the fully loaded rail vehicle was examined with the rail irregularity described in Figure 11 at a maximum operation speed of $80 \mathrm{~km} / \mathrm{h}$. Figures 20 and 21 show the vertical and angular displacements and accelerations of the rail vehicle body, respectively. The dynamic responses of the rail vehicle body were not very different compared to the second scenario that was under unloaded vehicle conditions. At this stage, where the same controller parameters were used, the vibrations below $10 \mathrm{~Hz}$ were well suppressed in the frequency domain (Figure 22). As the weight of the LRT vehicle increased, the maximum control force rose to about $7500 \mathrm{~N}$ as shown in Figure 23. Finally, all ISE values that were calculated as a performance index are presented in Table 6.

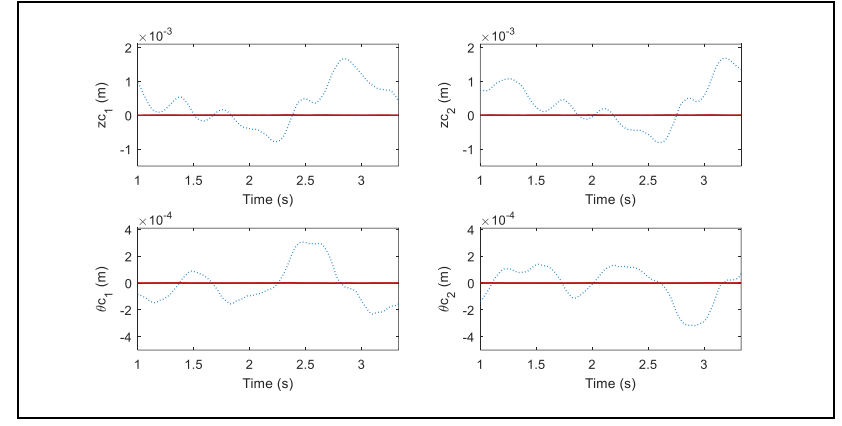

Figure 20. First and second car body displacements ( $\cdots$ Passive, - PID, ---Fuzzy).

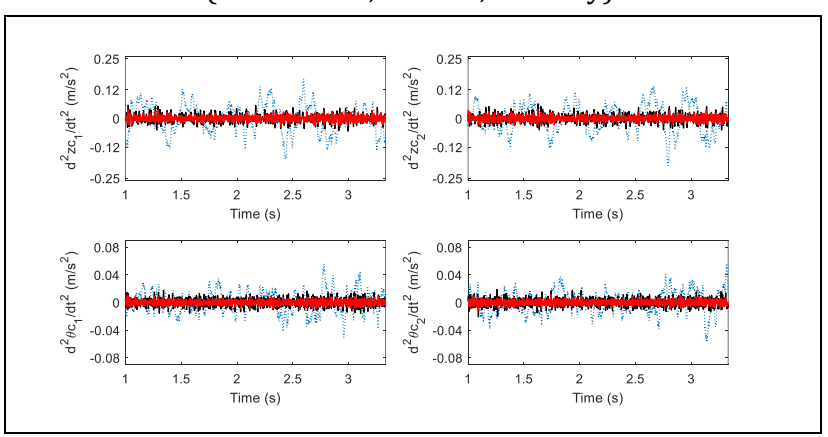

Figure 21. First and second car body accelerations ( $\cdots$ Passive, - PID, ---Fuzzy).

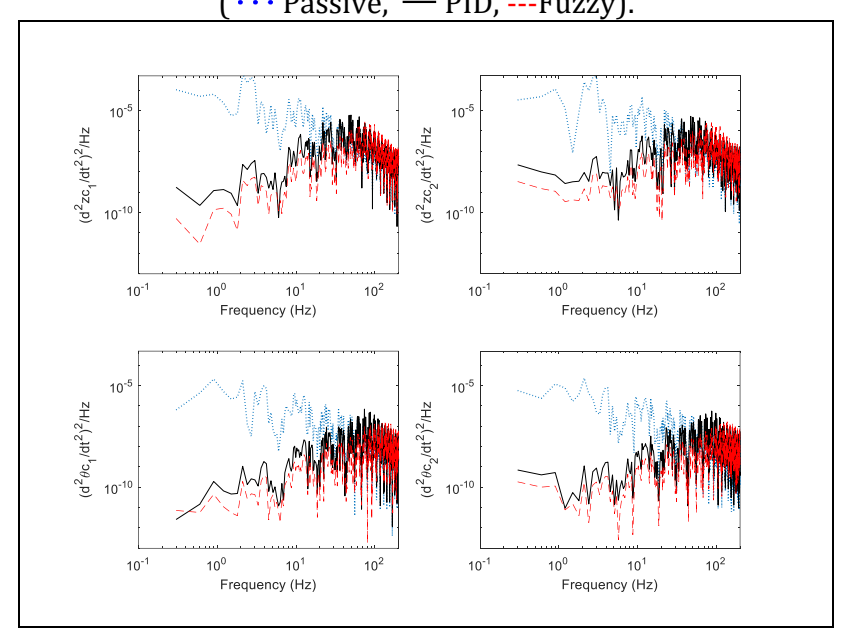

Figure 22. First and second car body PSD graphics

$$
\text { ( } \cdots \text { Passive, - PID, ---Fuzzy). }
$$

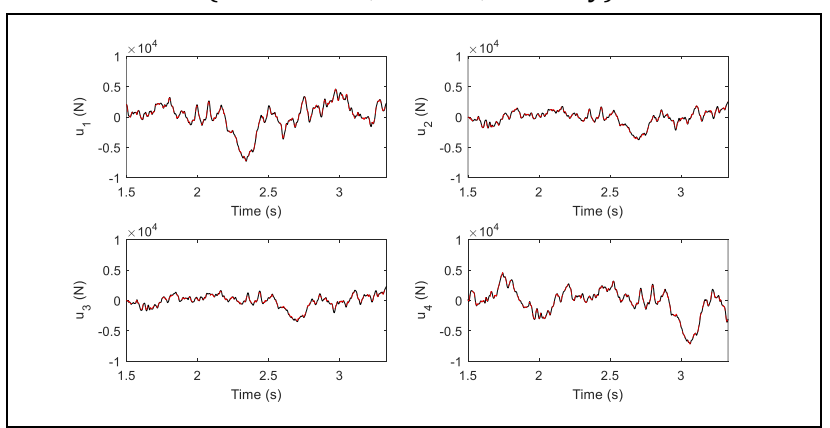

Figure 23. Comparison of control forces ( - PID, --- Fuzzy). 
Table 6. Calculated ISE values.

\begin{tabular}{ccccccccc}
\hline \multirow{2}{*}{$\begin{array}{c}\text { Controller } \\
\text { Forces }\end{array}$} & \multicolumn{2}{c}{ Case 1 } & \multicolumn{2}{c}{ Case 2 } & \multicolumn{2}{c}{ Case 3 } & \multicolumn{2}{c}{ Case 4 } \\
\cline { 2 - 9 } & PID & FLC & PID & FLC & PID & FLC & PID & FLC \\
\hline $\mathrm{u}_{1}$ & $0.81 \mathrm{e}-12$ & $0.97 \mathrm{e}-12$ & $0.72 \mathrm{e}-10$ & $0.12 \mathrm{e}-10$ & $0.25 \mathrm{e}-11$ & $0.03 \mathrm{e}-11$ & $0.51 \mathrm{e}-10$ & $0.01 \mathrm{e}-10$ \\
\hline $\mathrm{u}_{2}$ & $0.33 \mathrm{e}-12$ & $0.43 \mathrm{e}-12$ & $0.20 \mathrm{e}-10$ & $0.03 \mathrm{e}-10$ & $0.11 \mathrm{e}-11$ & $0.01 \mathrm{e}-11$ & $0.14 \mathrm{e}-10$ & $0.02 \mathrm{e}-10$ \\
\hline $\mathrm{u}_{3}$ & $0.29-12$ & $0.03 \mathrm{e}-12$ & $0.17 \mathrm{e}-10$ & $0.02 \mathrm{e}-10$ & $0.10 \mathrm{e}-11$ & $0.01 \mathrm{e}-11$ & $0.12 \mathrm{e}-10$ & $0.02 \mathrm{e}-10$ \\
\hline $\mathrm{u}_{4}$ & $0.92 \mathrm{e}-12$ & $0.12 \mathrm{e}-12$ & $0.55 \mathrm{e}-10$ & $0.09 \mathrm{e}-10$ & $0.28 \mathrm{e}-11$ & $0.03 \mathrm{e}-11$ & $0.4 \mathrm{e}-10$ & $0.08 \mathrm{e}-10$ \\
\hline
\end{tabular}

The model of the track consisted of an Euler-Bernoulli beam resting on discrete supported rail pads, which were connected as a viscoelastic foundation to a rigid ground. Moreover, a 16 DOF light rail vehicle, which allows studying vertical vibrations, was modelled using the Lagrange method. The train-track interaction was achieved by using a Hertz spring at the wheelrail contact. Furthermore, Galerkin's method was used to establish the mathematical model of the coupled system. All the governed equations were solved in MATLAB by using a fixed step size (2e-5) with the ode8 solver. Then, the FL and PID controllers were designed to suppress the vertical vibrations on the vehicle bodies generated by the effects of the transition zones with and without rail irregularities.

\section{Conclusion}

Passengers have been using the railroads to travel for more than a hundred years. With the increase in passenger expectations and travel speeds, the need for a safer, more comfortable and quieter transportation has emerged. In this study, which aimed to increase passenger comfort, a train-track coupled system was modelled interactively. Furthermore, the vehicle vibrations resulting from the effects of the transition zone due to the stiffness variation of the superstructure (with or without rail irregularity) were suppressed by two different controllers under different loading conditions.

In order to investigate these combined effects on the rail vehicle body, four different scenarios listed in Table 3 were contemplated. These scenarios were developed to demonstrate the success and stability of the controllers. The success of the control algorithms was evaluated comparatively in both time and frequency domains for all scenarios. In the comparison, the ISE performance indices and PSDs of the responses were analyzed in time and frequency domains, respectively. When the time and frequency responses were examined, the following results were obtained:

- For the displacement, the railway superstructure transition zone effects were almost destroyed by both controllers,

- $\quad$ Rail irregularity effects were much more dominant than transitional effects caused by different railway superstructure stiffness values,

- When the vehicle was fully loaded, the transition effects increased by about 2 times in displacement and accelerations of the rail vehicle body, in comparison to the unloaded condition. However, control achievements did not change even when the same control gains were used. On the other hand, the control forces that were generated increased by 2 times,

- In the worst scenario, the results of the fully loaded rail vehicle vibrations under the effects of rail superstructure transition and rail irregularity at maximum speed were not very different from the second scenario. This shows that the most dominant effect in terms of vibration in the scenarios was the irregularity of the track,

- It was seen that FLC produced more successful results than the PID controller for all scenarios despite the almost equal control force requirements of both controllers.

Consequently, an original study was presented by the use of the combined train-track interactive model to suppress rail vehicle vibrations actively. Additionally, 4 different dynamic scenarios were developed to test the stability of the controllers that were used. As in this study, more realistic results may be obtained by using these and similar train-track interactive models in subsequent studies to be developed.

\section{Nomenclature}

\begin{tabular}{|c|c|}
\hline & Roman Symbols \\
\hline A & : $\quad$ Cross-sectional area of rail, \\
\hline $\mathrm{c}_{1}$ & primary damping of suspension, \\
\hline $\mathrm{c}_{2}$ & secondary damping of suspension, \\
\hline$c_{h}$ & Hertz theory coefficient, \\
\hline$C_{\mathrm{rp}}$ & Damping coefficient of the rail pad, \\
\hline $\mathrm{E}$ & Young modulus of rail, \\
\hline $\mathrm{F}_{\mathrm{BC}}$ & Force between bogie and car, \\
\hline $\mathrm{F}_{\mathrm{BW}}$ & Force between bogie and wheel, \\
\hline $\mathrm{F}_{\mathrm{k} 22}$ & Force between $2^{\text {nd }}$ bogie and $1^{\text {st }}$ car body, \\
\hline $\mathrm{F}_{\mathrm{kc} 2}$ & Force between two car body, \\
\hline $\mathrm{F}_{\mathrm{RW}}$ & Force between rail and wheel, \\
\hline $\mathrm{F}_{\mathrm{RP}}$ & Force of rail pads, \\
\hline g & Gravitational acceleration, \\
\hline I & The $2^{\text {nd }}$ moment of area of the rail, \\
\hline $\mathrm{Jb}$ & Inertia moment of the bogie, \\
\hline $\mathrm{J}_{\mathrm{c}}$ & Inertia moment of the car body, \\
\hline $\mathrm{k}_{1}$ & primary stiffness of suspension, \\
\hline $\mathrm{k}_{2}$ & secondary stiffness of suspension, \\
\hline $\mathrm{k}_{\mathrm{h}}$ & Hertz spring, \\
\hline $\mathrm{k}_{\mathrm{rp}}$ & Stiffness coefficient of the rail pad, \\
\hline $\mathrm{L}$ & Length of the rail, \\
\hline $\mathrm{La}_{\mathrm{a}}$ & Length of the bogie, \\
\hline Lt & Length of the car body, \\
\hline M & Total numbers of rail pads, \\
\hline $\mathrm{Mb}$ & Mass of the bogie, \\
\hline Mc & Mass of the car body, \\
\hline Mw & Mass of the wheel, \\
\hline $\mathrm{N}$ & Total numbers of modes, \\
\hline Pw & Static force of wheel, \\
\hline$q(t)$ & Rail's degree of freedom, \\
\hline Rw & Radius of wheel, \\
\hline t & Time, \\
\hline $\mathrm{V}$ & Velocity of the train, \\
\hline$w r(x, t)$ & Vertical displacement of the rail, \\
\hline $\mathrm{zb}(\mathrm{t})$ & Vertical displacement of the bogie, \\
\hline $\mathrm{zc}(\mathrm{t})$ & Vertical displacement of the car body, \\
\hline $\mathrm{zr}$ & Rail irregularity, \\
\hline $\mathrm{zw}(\mathrm{t})$ & : Vertical displacement of the wheel. \\
\hline
\end{tabular}




\begin{tabular}{lll}
\hline & & \multicolumn{1}{c}{ Greek Symbols } \\
\hline$\eta$ & $:$ & Rail pad locations, \\
$\theta_{\mathrm{b}}(\mathrm{t})$ & $:$ & Rotational displacement of the bogie, \\
$\theta_{\mathrm{c}}(\mathrm{t})$ & $:$ & Rotational displacement of the car body, \\
$\xi$ & $:$ & Distance of between the train wheels, \\
$\rho$ & $:$ & Density of the rail, \\
$\Phi(\Omega)$ & $:$ & PSD function of rail irregularity, \\
$\varphi(\mathrm{x})$ & $:$ & Shape function.
\end{tabular}

\section{References}

[1] Ang KK, Dai J. "Response analysis of high-speed rail system accounting for abrupt change of foundation stiffness". Journal of Sound and Vibration, 332(12), 2954-2970, 2013.

[2] Lei X, Zhang B. "Influence of Track Stiffness Distribution on Vehicle and Track Interactions in Track Transition". Proceedings of the Institution of Mechanical Engineers, Part F: Journal of Rail and Rapid Transit, 224(6), 592-604, 2010.

[3] Zhai W, Cai Z. "Dynamic interaction between a lumped mass vehicle and a discretely supported continuous rail track". Computers \& Structures, 63(5), 987-997, 1997.

[4] Li D, Elkins JA, Otter DE, Wilson NG "Vehicle/track dynamic models for wheel/rail forces and track response". International Journal of Heavy Vehicle Systems, 6(1), 345-359, 1999.

[5] Zboinski K. "The importance of kinematics accuracy in modelling the dynamics of rail vehicle moving in a curved track with variable velocity". International Journal of Heavy Vehicle Systems, 18(4), 411-446, 2011.

[6] Esen I, Mırak C. "The optimisation of rail vehicle bogie parameters with the fuzzy logic method in order to improve passenger comfort during passage over bridges". International Journal of Heavy Vehicle Systems, 24(2), 113-139, 2017.

[7] Lei X. High Speed Railway Track Dynamics. Nanchang, China, Springer, 2017.

[8] Fortunato E, Paixão A, Calçada R. "Railway Track Transition Zones: Design, Construction, Monitoring and Numerical Modelling". International Journal of Railway Technology, 2(4), 33-58, 2013.

[9] Nicks JE. The Bump at the end of the Railway Bridge. PhD Thesis, Texas A\&M University, Texas, USA , 2009.

[10] Paixão A, Varandas JN, Fortunato E, Calçada R. "Numerical simulations to improve the use of under sleeper pads at transition zones to railway bridges". Engineering Structures, 164, 169-182, 2018.

[11] Sañudo R, Dellolio L, Casado J, Carrascal I, Diego S. "Track transitions in railways: A review". Construction and Building Materials, 112, 140-157, 2016.

[12] Li D, Davis D. "Transition of Railroad Bridge Approaches". Journal of Geotechnical and Geoenvironmental Engineering, 131(11), 1392-1398, 2005.

[13] Palomo ML, Barceló FR, Llario FR, Herráiz JR. "Effect of vehicle speed on the dynamics of track transitions".Journal of Vibration and Control, 24(21), 5118-5128, 2018.

[14] Esmaeili M, Mosayebi SA, Zakeri JA. "Effects of sleeper support modulus on dynamic behaviour of railway tracks caused by moving wagon". International Journal of Heavy Vehicle Systems, 24(3), 277-287, 2017.

[15] Kerr AD, Moroney BE. "Track Transition Problems and Remedies". American Railway Engineering AssociationBulletin, 742, 267-298, 1993.
[16] Namura A, Suzuki T. "Evaluation of Countermeasures against Differential Settlement at Track Transitions". Quarterly Report of RTRI, 2007.

[17] Read D, Li D. "Design of Track Transitions". TCRP Research Results Digest, 79, 2006.

[18] Paixão A, Fortunato E, Calçada R. "Design and construction of backfills for railway track transition zones". Proceedings of the Institution of Mechanical Engineers, Part F: Journal of Rail and Rapid Transit, 229(1), 58-70, 2013.

[19] Bruni S, Vinolas J, Berg M, Polach O, Stichel S. "Modelling of suspension components in a rail vehicle dynamics context". Vehicle System Dynamics, 49(7), 1021-1072, 2011.

[20] Hirata T, Koizumi S, Takahashi R. "Hळ Control of railroad vehicle active suspension". Automatica, 31(1), 13-24, 1995.

[21] Li H, Goodall RM. "Linear and non-linear skyhook damping control laws for active railway suspensions". Control Engineering Practice, 7(7), 843-850, 1999.

[22] Mei T, Goodall RM. "LQG and GA solutions for active steering of railway vehicles". IEEE Proceedings-Control Theory and Applications, 147(1), 111-117, 2000.

[23] Guclu R, Metin M. "Fuzzy Logic Control of Vibrations of a Light Rail Transport Vehicle in Use in Istanbul Traffic".Journal of Vibration and Control, 15(9), 1423-1440, 2009.

[24] Fateh MM, Alavi SS. "Impedance control of an active suspension system”. Mechatronics, 19(1), 134-140, 2009.

[25] Pacchioni A, Goodall RM, Bruni, S. "Active suspension for a two-axle railway vehicle". Vehicle System Dynamics, 48(sup1), 105-120, 2010.

[26] Metin M, Guclu R. "Vibrations control of light rail transportation vehicle via PID type fuzzy controller using parameters adaptive method". Turkish Journal of Electrical Engineering and Computer Sciences, 19, 807-816, 2011.

[27] Metin M, Guclu R. "Rail Vehicle Vibrations Control Using Parameters Adaptive PID Controller". Mathematical Problems in Engineering, 2014, 1-10, 2014.

[28] Choi SB, Lee HS, Park YP. "H8 Control Performance of a Full-Vehicle Suspension Featuring Magnetorheological Dampers". Vehicle System Dynamics, 38(5), 341-360, 2002.

[29] Eslaminasab N, Biglarbegian M, Melek WW, Golnaraghi MF. "A neural network based fuzzy control approach to improve ride comfort and road handling of heavy vehicles using semi-active dampers". International Journal of Heavy Vehicle Systems, 14(2), 135-157, 2007.

[30] Wang DH, Liao WH. "Semi-active suspension systems for railway vehicles using magnetorheological dampers. Part I: system integration and modelling". Vehicle System Dynamics, 47(11), 1305-1325, 2009.

[31] Wang DH, Liao WH. "Semi-active suspension systems for railway vehicles using magnetorheological dampers. Part II: simulation and analysis". Vehicle System Dynamics, 47(12), 1439-1471, 2009.

[32] He J, Chen Y, Zhao C, Qi Z, Ren X. "Heavy truck suspension optimisation based on modified skyhook damping control". International Journal of Heavy Vehicle Systems, 18(2), 161-178, 2011.

[33] Pratt I. Active Suspensions Applied to Railway Trains. PhD Thesis, Loughborough University, Leicestershire, UK, 1996. 
[34] Suda Y, Wang W, Komine H, Sato Y, Nakai T, Shimokawa Y. "Study on control of air suspension system for railway vehicle to prevent wheel load reduction at low-speed transition curve negotiation". Vehicle System Dynamics, 44 0, 814-822, 2006.

[35] Bruni S, Goodall RM, Mei TX, Tsunashima H. "Control and monitoring for railway vehicle Dynamics". Vehicle System Dynamics, 45(7-8), 743-779, 2007.

[36] Li S, Yang S, Chen L, Lu Y. "Effects of parameters on dynamic responses for a heavy vehicle-pavementfoundation coupled system". International Journal of Heavy Vehicle Systems, 19(2), 207-224, 2012.

[37] Aström KJ, Hägglund T. PID Controllers: Theory, Design, and Tuning. $2^{\text {nd }}$ ed. North Carolina, USA, International Society of Automation, 1995.

[38] Aström KJ, Hägglund T. "The future of PID control". Control Engineering Practice, 9(11), 1163-1175, 2001.

[39] Araki M. PID Control In: Control Systems, Robotics and Automation System Analysis and Control, Vol. II, EOLSS Publications, 2009.

[40] Zadeh LA. "Fuzzy sets". Information and Control, 8(3), 338-353, 1965.

[41] Mamdani E, Assilian S. "An experiment in linguistic synthesis with a fuzzy logic controller". International Journal of Man-Machine Studies, 7(1), 1-13, 1975.

\section{Appendix A}

Railway train vehicle differential equations are given below. Equations (6-8) represent the dynamics of 6 wheelsets, 3 bogies and 2 car bodies.

$$
\begin{gathered}
M_{w 1} \ddot{z}_{w 1}(t)-F_{B 1 W 1}+F_{R W 1}-M_{w 1} g=0 \\
M_{w 2} \ddot{z}_{w 2}(t)-F_{B 1 W 2}+F_{R W 2}-M_{w 2} g=0 \\
M_{w 3} \ddot{z}_{w 3}(t)-F_{B 2 W 3}+F_{R W 3}-M_{w 3} g=0 \\
M_{w 4} \ddot{z}_{w 4}(t)-F_{B 2 W 4}+F_{R W 4}-M_{w 4} g=0 \\
M_{w 5} \ddot{z}_{w 5}(t)-F_{B 3 W 5}+F_{R W 5}-M_{w 5} g=0 \\
M_{w 6} \ddot{z}_{w 6}(t)-F_{B 3 W 6}+F_{R W 6}-M_{w 6} g=0 \\
M_{b 1} \ddot{z}_{b 1}(t)+F_{B 1 W 1}+F_{B 1 W 2}-F_{B 1 C 1}-u_{1}=0 \\
J_{b 1} \ddot{\theta}_{b 1}(t)+L_{a} F_{B 1 W 1}-L_{a} F_{B 1 W 2}=0 \\
M_{b 2} \ddot{z}_{b 2}(t)+F_{B 2 W 3}+F_{B 2 W 4}-F_{k 22}-u_{2}-u_{3}=0 \\
J_{b 2} \ddot{\theta}_{b 2}(t)+L_{a} F_{B 2 W 3}-L_{a} F_{B 2 W 4}=0 \\
M_{b 3} \ddot{z}_{b 3}(t)+F_{B 3 W 5}+F_{B 3 W 6}-F_{B 3 C 2}-u_{4}=0 \\
J_{b 3} \ddot{\theta}_{b 3}(t)+L_{a} F_{B 3 W 5}+L_{a} F_{B 3 W 6}=0 \\
M_{c 1} \ddot{z}_{c 1}(t)+F_{B 1 C 1}+F_{k 22}-F_{k c 2}+u_{1}+u_{2}=0 \\
J_{c 1} \ddot{\theta}_{c 1}(t)+\left(L_{a}+L_{t}\right) F_{B 1 C 1}-\left(L_{a}+L_{t}\right) F_{k 22} \\
+\left(L_{a}+L_{t}\right) F_{k c 2}+u_{1}\left(L_{a}+L_{t}\right)-u_{2}\left(L_{a}+L_{t}\right)=0 \\
M_{c 2} \ddot{z}_{c 2}(t)+F_{B 3 C 2}+F_{\mathrm{kc} 2}+u_{3}+u_{4}=0 \\
J_{c 2} \ddot{\theta}_{c 2}(t)-\left(L_{a}+L_{t}\right) F_{B 3 C 2}-\left(L_{a}+L_{t}\right) F_{\mathrm{kc} 2} \\
-u_{3}\left(L_{a}+L_{t}\right)+u_{4}\left(L_{a}+L_{t}\right)=0
\end{gathered}
$$

$F_{B W}, F_{B C}$ and $F_{R W}$ respectively represent the interaction force between bogie and wheel in equation (9), the interaction force between bogie and car in equation (10), the interaction force between rail and wheel in Equation (11).

$$
\begin{gathered}
F_{B 1 W 1}=k_{11}\left(z_{b 1}(t)-z_{w 1}(t)+L_{a} \theta_{b 1}(t)\right) \\
+c_{11}\left(\dot{z}_{b 1}(t)-\dot{z}_{w 1}(t)+L_{a} \dot{\theta}_{b 1}(t)\right) \\
F_{B 1 W 2}=k_{12}\left(z_{b 1}(t)-z_{w 2}(t)-L_{a} \theta_{b 1}(t)\right) \\
+c_{12}\left(\dot{z}_{b 1}(t)-\dot{z}_{w 2}(t)-L_{a} \dot{\theta}_{b 1}(t)\right) \\
F_{B 2 W 3}=k_{13}\left(z_{b 2}(t)-z_{w 3}(t)+L_{a} \theta_{b 2}(t)\right) \\
+c_{13}\left(\dot{z}_{b 2}(t)-\dot{z}_{w 3}(t)+L_{a} \dot{\theta}_{b 2}(t)\right) \\
F_{B 2 W 4}=k_{14}\left(z_{b 2}(t)-z_{w 4}(t)-L_{a} \theta_{b 2}(t)\right) \\
+c_{14}\left(\dot{z}_{b 2}(t)-\dot{z}_{w 4}(t)-L_{a} \dot{\theta}_{b 2}(t)\right) \\
F_{B 3 W 5=} k_{15}\left(z_{b 3}(t)-z_{w 5}(t)+L_{a} \theta_{b 3}(t)\right) \\
+c_{15}\left(\dot{z}_{b 3}(t)-\dot{z}_{w 5}(t)+L_{a} \dot{\theta}_{b 3}(t)\right) \\
F_{B 3 W 6}=k_{16}\left(z_{b 3}(t)-z_{w 6}(t)-L_{a} \theta_{b 3}(t)\right) \\
+c_{16}\left(\dot{z}_{b 3}(t)-\dot{z}_{w 6}(t)-L_{a} \dot{\theta}_{b 3}(t)\right) \\
\left.\quad-\left(L_{a}+L_{t}\right) \theta_{\mathrm{c} 2}(t)\right) \\
F_{B 1 \mathrm{C} 1}=k_{21}\left(z_{\mathrm{c} 1}(t)-z_{\mathrm{b} 1}(t)+\left(L_{a}+L_{t}\right) \theta_{\mathrm{c} 1}(t)\right) \\
+c_{21}\left(\dot{z}_{\mathrm{c} 1}(t)-\dot{z}_{\mathrm{b} 1}(t)+\left(L_{a}+L_{t}\right) \dot{\theta}_{c 1}(t)\right) \\
F_{B 3 \mathrm{C} 2}=k_{23}\left(z_{\mathrm{c} 2}(t)-z_{\mathrm{b} 3}(t)+\left(L_{a}+L_{t}\right) \theta_{\mathrm{c} 2}(t)\right) \\
+c_{23}\left(\dot{z}_{\mathrm{c} 2}(t)-\dot{z}_{\mathrm{b} 3}(t)+\left(L_{a}+L_{t}\right) \dot{\theta}_{c 2}(t)\right) \\
F_{k 22}=k_{22}\left(z_{\mathrm{c} 1}(t)-z_{\mathrm{b} 2}(t)-\left(L_{a}+L_{t}\right) \theta_{\mathrm{c} 1}(t)\right) \\
+c_{22}\left(\dot{z}_{\mathrm{c} 1}(t)-\dot{z}_{\mathrm{b} 2}(t)-\left(L_{a}+L_{t}\right) \dot{\theta}_{c 1}(t)\right) \\
F_{k c 2}=k_{\mathrm{c} 2}\left(z_{\mathrm{c} 2}(t)-z_{c 1}(t)+\left(L_{a}+L_{t}\right) \theta_{\mathrm{c}}\right.
\end{gathered}
$$

Linear Hertz spring force acting on each wheel is calculated as following form,

$$
\begin{gathered}
F_{R W m}=k_{h}\left(z_{w m}(t)-\sum_{j=1}^{n} q_{j}(t) \varphi_{i}\left(v t-\xi_{m}\right)-Z_{r m}(t)\right) \\
Z_{r m}(t)=z_{r}\left(v t-\xi_{m}\right), m=1, \ldots, 6
\end{gathered}
$$

The trivial function according to boundary conditions that is used in the is given in below in equation (12)

$$
w_{r}(x, t)=\sum_{i=1}^{N} q_{i}(t) \varphi_{i}(x), \quad \varphi_{i}(x)=\sin \left(\frac{i \pi x}{L}\right)
$$

For the track system, the derived equations are represented in equation (13),

$$
\begin{gathered}
\frac{L}{2}\left\{\left[E I\left(\frac{i \pi}{L}\right)^{4}\right] q_{i}(t)+\rho A \ddot{q}_{i}(t)\right\}+F_{R P}-F_{W}=0, \\
i=1,2, \ldots, N
\end{gathered}
$$

Where, $F_{R P}$ and $F_{W}$ represent forces that act on the rail from rail pads and wheels. Wheel-rail force that is called a linear Hertz spring force is calculated in equation (14) as the following, 


$$
\begin{gathered}
F_{W}=\sum_{m=1}^{6} k_{h m}\left[z_{w m}(t) \varphi_{i}\left(v t-\xi_{m}\right)-f_{r}-Z_{r m}\right] \\
f_{r}=\sum_{j=1}^{n} q_{j}(t) \varphi_{i}\left(v t-\xi_{m}\right) \varphi_{j}\left(v t-\xi_{m}\right)
\end{gathered}
$$

The interaction force between rail and rail pad is represented in equation

$$
\begin{aligned}
F_{R P}= & k_{r p}\left[\sum_{m=1}^{M} \sum_{k=1}^{N} q_{k}(t) \varphi_{k}\left(\eta_{m}\right) \varphi_{i}\left(\eta_{m}\right)\right] \\
& +c_{r p}\left[\sum_{m=1}^{M} \sum_{k=1}^{N} \dot{q}_{k}(t) \varphi_{k}\left(\eta_{m}\right) \varphi_{i}\left(\eta_{m}\right)\right]
\end{aligned}
$$

where $M$ is represented as the number of rail pads and taken in total as 130 composed of 40-40-50 rail pads for each zone. The linear Hertz spring coefficient that is calculated for each wheel when the wheel tread is conic in shape is given in equation (16) [7].

$$
\begin{gathered}
k_{h m}=(3 / 2) c_{h m}^{3 / 2} P_{w m}^{1 / 3}, \mathrm{~m}=1, \ldots, 6 \\
c_{h m}=\left(4.57 R_{w}^{-0.149} 10^{-8}\right)^{-3 / 2}, \mathrm{~m}=1, \ldots, 6
\end{gathered}
$$

